\title{
Field evaluation of new plant protection products against Plasmopara viticola
}

\author{
L. Bavaresco, C. Squeri, and A. Vercesi \\ Department of Sustainable Crop Production, Università Cattolica del Sacro Cuore, Piacenza, Italy
}

\begin{abstract}
One of the most dangerous fungal diseases in viticulture is downy mildew. Copper-based active ingredients have been used for a long time to protect vines against Plasmopara viticola and they have always maintained an important role in the defense of vines especially for organic production. On the other hand, copper accumulates in the soil causing toxicity with negative consequences on plants and soil fauna. For this reason, new formulations with lower copper content have been considered. In recent years, foliar fertilizers have been studied, in particular those based on phosphites that, along with the nutritional function, stimulate the production of phytoalexins. Those metabolites cause the induced systemic resistance and act directly in the break of cell membranes of pathogens. This study aims to investigate the efficacy against downy mildew of a commercial product based on phosphites and of a new copper- based foliar fertilizer, where copper is chelated with gluconic acid and aminoacids of plant origin. Based on present results, phosphites significantly reduced the infection, without anyway achieving the defense effectiveness of the copper-based treatment however they ensure a significant reduction of the doses of copper necessary to achieve adequate levels of vineyard protection.
\end{abstract}

\section{Introduction}

Plamopara viticola entered France most likely in 1878 with the American propagation material imported to face the devastation of the vineyards by phylloxera. Some years later some documents reported on the occurrence of the disease in northwest Italy [1,2]. Therefore, for 140 years, downy mildew is affecting European viticulture.

\subsection{Active ingredients of the antiperonosporic defence}

Until the end of the first half of the 20th century, the chemical defence of Plasmopara viticola was carried out exclusively with copper-based compounds. Subsequently, industrial synthesis products with covering and preventive action were introduced, especially including dithiocarbamates from the '50s onwards [2,3]. Since the end of the ' $70 \mathrm{~s}$, new endotherapic active ingredients have been developed entering the tissues of the foilage having not only a preventive but also a curative effect on the infection [4,5]. However, these synthetic products have shown two drawbacks: sanitary for humans, in particular dithiocarbamates [6]; and decreased efficacy by stimulating the formation of resistant fungal strains, such as anilides and cymoxanil [7-9]. For this reason, in recent decades, several other highly effective and less inconvenient synthetic substances have been introduced on the market, both with endotherapic action (e.g., iprovalicarb, fluopicolide) and coverage, but very persistent (e.g., fomaxadone, zoxamide) [8]

\subsection{Organic defence and the role of copper}

More recently, the reduction in the use of substances of industrial synthesis and sustainability have become key points in grape production.

In this context, organic viticulture, regulated by the EU since 1991 (ECC 2092/91, later replaced by EC 834/2007), has been developed, which allows the use of only natural substances in the production process, including copper for defense against downy mildew.

To counter the large increasing use of copper the EU implemented an upper limit of $6 \mathrm{~kg} / \mathrm{ha} /$ year, even if a complete protection is difficult to be ensured. Over the years copper, as any heavy metal, accumulates in the soil causing a modification of soil characteristics and a reduction of the microbial biomass and activity [10]. For this reason, substances of natural origin and low environmental impact are also increasingly used like for example: propolis, rock meal, mixtures of micro-organisms, plant and/or algae extracts, phosphates, phosphites [11-15].

\subsection{Phosphites}

Foliar fertilizers based on potassium phosphite and magnesium phosphite have been shown to be very effective against grape downy mildew [16-19]. Phosphites are elicitors of defence reactions promoting the production of phytoalexins which are fungitoxic compounds normally produced by plant tissues and accumulated at high levels to respond to pathogen attack. In addition to Systemic Induced Resistance, phytoalexins act directly on cell membranes of pathogenic micro-organisms, causing their destruction and evoking curative action [20]. For 
these reasons, some fertilizer producers are providing commercial products based on phosphites, to be used in viticulture.

\section{Material and methods}

The trial was carried out in 2015 in a non-irrigated vineyard of 15-year-old V. vinifera L. cv. Barbera vines grafted on SO4 and grown in Vigolzone (Piacenza province, Italy). The vineyard was north-south oriented, vine spacing is $2.5 \mathrm{~m} \times 1.6 \mathrm{~m}$, Guyot trellis.

\subsection{Treatments and meteorological data}

Four treatments were compared, as follows: traditional product based on copper called Poltiglia Disperss $2.5 \mathrm{~kg} / \mathrm{ha}$ every 7 days $(\mathrm{Cu})$; Poltiglia Disperss $1.3 \mathrm{~kg} / \mathrm{ha}+$ Scudo $1.0 \mathrm{~L} /$ ha every 7 days $(\mathrm{CuS})$; Phosphit-One $2.2 \mathrm{~L} / \mathrm{ha}+$ Scudo $1.5 \mathrm{~L} / \mathrm{ha}$ every 12 days at the beginning of the season, then switching to intervals of 7 days starting from June (PhoS); untreated (control) vines. The total amount of treatments was 9 per season for $\mathrm{Cu}$ and $\mathrm{CuS}$, and 10 per season for PhoS.

"Poltiglia Disperss" is the traditional product used against downy mildew (20\% Cu). "Scudo" is a liquid fertilizer produced by Italpollina company $(11.7 \% \mathrm{Cu}$ chelated by gluconic acid and amino acids of plant origin to ensure a good uptake by leaves). "Phosphit-One" is a phosphites-based fertilizer produced by Italpollina company $\left(30 \% \mathrm{P}_{2} \mathrm{O}_{5}\right)$.

For each treatment two monitoring blocks were set up, one in the most vigorous part of the vineyard, and the other one in the least vigorous part; 4 plants/block were examined for a total of 8 plants/treatment.

Seasonal weather was monitored by a meteorological station located in the vineyard.

\subsection{Downy mildew assessment}

The evaluation of the downy mildew attack on leaves and bunches was visually assessed [21] twice during the season $\left(1^{\text {st }}\right.$ July and $4^{\text {th }}$ August) on the basis of the following damage classes: healthy $(0 \%) ; 1-5 \% ; 5-12.5 \% ; 13$, $5-25 \% ; 26-50 \%$ and $51-100 \%$.

\subsection{Yield and fruit composition}

At grape harvest (16 September 2015), all bunches per vine were counted, their total mass was immediately recorded, and the average bunch mass was then calculated. A threebunch-sample was collected from each tagged vine to be processed in laboratory.

From each sample, a 50-berry-subsample was processed to analyze the concentration of anthocyanin and phenolic compounds [22]. Berries were thawed at room temperature and then homogenized at high speed with a UltraTurrax (Rose Scientific, Edmonton, AB, Canada) for $1 \mathrm{~min}$. A $2 \mathrm{~g}$ sample of the homogenized material was transferred to a centrifuge tube containing $10 \mathrm{~mL}$ of aqueous ethanol (50\%, pH 5.0), capped and mixed before centrifugation at $960 \times \mathrm{g}$ for $5 \mathrm{~min}$. A $0.5 \mathrm{~mL}$ aliquot of the extract was added to $10 \mathrm{~mL} 1 \mathrm{~mol} \mathrm{HCl}$, mixed and allowed to stand for $3 \mathrm{~h}$. Absorbance at 520 and $280 \mathrm{~nm}$ was measured by a Jasco V-530
Table 1. Monthly average temperature and total rainfall (2015).

\begin{tabular}{|c|c|c|}
\hline & $\begin{array}{c}\text { Average } \\
\text { temperature }\left({ }^{\circ} \mathbf{C}\right)\end{array}$ & $\begin{array}{c}\text { Rainfall } \\
(\mathbf{m m})\end{array}$ \\
\hline May & 19 & 42.5 \\
\hline June & 23 & 37.0 \\
\hline July & 28 & 3.0 \\
\hline August & 25 & 48.5 \\
\hline September & 21 & 62.5 \\
\hline
\end{tabular}

UV-spectrophotometer; relative calculations were performed to express the concentration of anthocyanin and phenolic substances as $\mathrm{mg} / \mathrm{berry}$ and $\mathrm{g} / \mathrm{L}$.

The remaining berries of each three-bunch-sample were crushed, and the total soluble solids (TSS, ${ }^{\circ}$ Brix) was recorded by a temperature compensating refractometer (RX-5000 ATAGO USA, Bellevue, WA, USA). Titratable acidity (TA) was measured by titration with $0.1 \mathrm{~N} \mathrm{NaOH}$ to a $\mathrm{pH} 8.2$ endpoint and expressed as grams per liter of tartaric acid equivalents.

The analyses of the copper and phosphorous acid residue in the must were performed by the Edmund Mach Foundation, at S. Michele a/A, Italy. For copper residue, the method used includes the use of the plasma atomic emission spectrometer (ICPOES, wavelength $327 \mathrm{~nm}$ ) after extraction with a solution of diluted nitric acid (5 g sample $+3 \mathrm{~mL}$ nitric acid brought to a final volume of $45 \mathrm{~mL}$ with ultrapure water). For the determination of phosphorous acid residue the method QuPPE was used [23]. The method allows the analysis of highly polar pesticides by simultaneous extraction with methanol and determination with LC-MS.

\subsection{Statistical analysis}

Data were analyzed by a two-way ANOVA using the IBM SPSS statistics 24 software package. When significant at ANOVA, treatment comparison was performed by Student-Newman-Keuls test at $P \leq 0.05$.

\section{Results and discussion}

\subsection{Meteorological data}

The meteorological data are reported in Table 1. The total rainfall (from May till September 2015) was $193.5 \mathrm{~mm}$. The average temperature of July was very high $\left(28^{\circ} \mathrm{C}\right)$ while the rainfall was very low $(3.0 \mathrm{~mm})$. These conditions most likely hindered the growth of Plasmopara viticola.

\subsection{Downy mildew evaluation}

The first symptoms of downy mildew (yellow areas on upper surface of the leaves), were visible since 20 May.

\subsection{1. $1^{\text {st }}$ July assessment (Table 2)}

The percentage of affected leaves was significantly the highest in the untreated vines (Control, 36.2\%), and the lowest in $\mathrm{CuS}(1.9 \%)$. The severity of the attack was the highest in the control (6.4\%) and the lowest in $\mathrm{CuS}(0.0 \%)$. The percentage of bunches affected by downy mildew in July did not appear to differ significantly among the treatments. 
Table 2. Detection of downy mildew damages at $1^{\text {st }}$ July depending on the treatments. L-Inc: leaf incidence; L-Sev: leaf severity; B-Inc: bunch incidence; B-Sev: bunch severity.

\begin{tabular}{|c|c|c|c|c|}
\hline & $\begin{array}{c}\text { L-Inc } \\
(\boldsymbol{\%})\end{array}$ & $\begin{array}{c}\text { L-Sev } \\
(\boldsymbol{\%})\end{array}$ & $\begin{array}{c}\text { B-Inc } \\
(\boldsymbol{\%})\end{array}$ & $\begin{array}{c}\text { B-Sev } \\
(\boldsymbol{\%})\end{array}$ \\
\hline $\mathrm{Cu}$ & $3.7 \mathrm{a}$ & $0.1 \mathrm{a}$ & 15.0 & 1.0 \\
\hline $\mathrm{CuS}$ & $1.9 \mathrm{a}$ & $0.0 \mathrm{a}$ & 19.4 & 4.7 \\
\hline $\mathrm{PhoS}$ & $9.7 \mathrm{ab}$ & $0.8 \mathrm{a}$ & 14.4 & 10.5 \\
\hline $\mathrm{Control}$ & $36.2 \mathrm{~b}$ & $6.4 \mathrm{~b}$ & 19.4 & 6.3 \\
\hline$F \mathrm{~T}$ & $12.6 * *$ & $12.6 * *$ & 24.8 n.s. & 7.5 n.s. \\
\hline$F \mathrm{~B}$ & 0.2 n.s. & 0.2 n.s. & 0.8 n.s. & 0.6 n.s. \\
\hline$F \mathrm{~T} \times \mathrm{B}$ & $10.2 * *$ & $10.2 * *$ & 3.5 n.s. & $21.7 * *$ \\
\hline
\end{tabular}

$* P \leq 0.05 ; * * P \leq 0.01$. Within each column, means followed by different letters are significantly different $(P<0.05)$ according to the Student-Newman-Keuls test. ns, not significant; T, treatments; B, blocks Cu: Poltiglia Disperss; CuS: Poltiglia Disperss + Scudo; PhoS Phosphit-One + Scudo.

Table 3. Detection of downy mildew damages at $4^{\text {th }}$ August depending on the treatments. L-Inc: leaf incidence; L-Sev: leaf severity; B-Inc: bunch incidence; B-Sev: bunch severity.

\begin{tabular}{|c|c|c|c|c|}
\hline & $\begin{array}{c}\text { L-Inc } \\
(\boldsymbol{\%})\end{array}$ & $\begin{array}{c}\text { L-Sev } \\
(\boldsymbol{\%})\end{array}$ & $\begin{array}{c}\text { B-Inc } \\
(\boldsymbol{\%})\end{array}$ & $\begin{array}{c}\text { B-Sev } \\
(\boldsymbol{\%})\end{array}$ \\
\hline $\mathrm{Cu}$ & $6.6 \mathrm{~b}$ & $0.3 \mathrm{a}$ & $21.4 \mathrm{a}$ & $0.6 \mathrm{a}$ \\
\hline $\mathrm{CuS}$ & $2.5 \mathrm{a}$ & $0.1 \mathrm{a}$ & $14.6 \mathrm{a}$ & $0.8 \mathrm{a}$ \\
\hline $\mathrm{PhoS}$ & $5.6 \mathrm{~b}$ & $0.2 \mathrm{a}$ & $23.5 \mathrm{a}$ & $0.8 \mathrm{a}$ \\
\hline $\mathrm{Control}$ & $13.4 \mathrm{c}$ & $2.1 \mathrm{~b}$ & $63.7 \mathrm{~b}$ & $8.4 \mathrm{~b}$ \\
\hline$F \mathrm{~T}$ & $14.7 * *$ & $8.9 * *$ & $15.4 * *$ & $18.2 * *$ \\
\hline$F \mathrm{~B}$ & 4.4 n.s. & $9.3 * *$ & $6.7 *$ & $15.1 * *$ \\
\hline$F \mathrm{~T} \times \mathrm{B}$ & 1.4 n.s. & $4.3 *$ & $11.8 * *$ & $16.8 * *$ \\
\hline
\end{tabular}

* $P \leq 0.05$; ** $P \leq 0.01$. Within each column, means followed by different letters are significantly different $(P<0.05)$ according to the Student-Newman-Keuls test. ns, not significant; T, treatments; B, blocks. Cu: Poltiglia Disperss; CuS: Poltiglia Disperss + Scudo; PhoS: Phosphit-One + Scudo.

\subsection{2. $4^{\text {th }}$ August assessment (Table 3)}

The highest percentage of affected leaves was recorded in the control (about 13.4\%), while the lowest was detected in $\mathrm{CuS}(2.5 \%)$. Similarly, the percentage of leaf damage appeared to be much higher in the untreated vines $(2.1 \%)$ than in the other treatments $(0.3 \%$ for $\mathrm{Cu}, 0.1 \%$ for $\mathrm{CuS}$, $0.2 \%$ for PhoS).

The percentage of affected clusters was significantly higher in the control $(63.7 \%)$ than in the other treatments (21.4\% for $\mathrm{Cu}, 14.6 \%$ for $\mathrm{CuS}, 23.5 \%$ for PhoS). The damage caused by downy mildew on the bunches was $8.4 \%$ in the control, while the other treatments showed significantly less damages $(0.6 \%$ for $\mathrm{Cu}, 0.8 \%$ for $\mathrm{CuS}$, $0.8 \%$ for PhoS).

\subsubsection{Yield components and fruit composition (Tables 4,5,6,7)}

At harvest, the average bunch weight did not differ significantly among the treatments, even though it ranged from $246 \mathrm{~g}$ (control) to $333 \mathrm{~g}$ (PhoS treatment). The average berry weight ranged from $1.2 \mathrm{~g}(\mathrm{Cu}$ treatment) to $2.4 \mathrm{~g}$ (PhoS treatment). As concerning the yield/vine the highest value was recorded for PhoS $(4.8 \mathrm{~kg})$ and the lowest for the control ( $3 \mathrm{~kg} / \mathrm{vine}$, about $30 \%$ less); $\mathrm{Cu}$ treatment induced a yield of $4.0 \mathrm{~kg} / \mathrm{vine}$, while the
Table 4. Yield components of Barbera grape variety depending on the treatments, at harvest.

\begin{tabular}{|c|c|c|c|}
\hline & $\begin{array}{c}\text { Bunch } \\
\text { mass }(\mathbf{g})\end{array}$ & $\begin{array}{c}\text { Berry } \\
\text { mass (g) }\end{array}$ & $\begin{array}{c}\text { Yield/vine } \\
(\mathbf{k g})\end{array}$ \\
\hline $\mathrm{Cu}$ & 280 & $1.2 \mathrm{a}$ & $4.0 \mathrm{ab}$ \\
\hline $\mathrm{CuS}$ & 317 & $2.2 \mathrm{ab}$ & $4.7 \mathrm{~b}$ \\
\hline $\mathrm{PhoS}$ & 333 & $2.4 \mathrm{~b}$ & $4.8 \mathrm{~b}$ \\
\hline Control & 246 & $2.3 \mathrm{~b}$ & $3.0 \mathrm{a}$ \\
\hline$F \mathrm{~T}$ & 2.6 n.s. & $4.0 *$ & $3.4 *$ \\
\hline$F \mathrm{~B}$ & 1.9 n.s. & $16.7^{* *}$ & 1.9 n.s. \\
\hline$F$ T x B & 1.6 n.s. & 0.4n.s. & 0.4 n.s. \\
\hline
\end{tabular}

* $P \leq 0.05$; ** $P \leq 0.01$. Within each column, means followed by different letters are significantly different $(P<0.05)$ according to the Student-Newman-Keuls test. ns, not significant; $\mathrm{T}$, treatments; B, blocks.

Cu: Poltiglia Disperss; CuS: Poltiglia Disperss + Scudo; PhoS: Phosphit-One + Scudo.

Table 5. Fruit composition of Barbera grape variety depending on the treatments, at harvest.

\begin{tabular}{|l|c|c|c|c|}
\hline & $\begin{array}{c}\text { TSS } \\
\left({ }^{\circ} \text { Brix }\right)\end{array}$ & $\begin{array}{c}\text { TA } \\
(\mathrm{g} / \mathbf{L})\end{array}$ & $\begin{array}{c}\text { Tartaric } \\
\text { acid }(\mathbf{g} / \mathbf{L})\end{array}$ & $\begin{array}{c}\text { Malic acid } \\
(\mathbf{g} / \mathbf{L})\end{array}$ \\
\hline $\mathrm{Cu}$ & $22.4 \mathrm{a}$ & 10.3 & 9.9 & $2.1 \mathrm{a}$ \\
\hline $\mathrm{CuS}$ & $23.3 \mathrm{a}$ & 10.7 & 9.8 & $2.5 \mathrm{a}$ \\
\hline $\mathrm{PhoS}$ & $23.8 \mathrm{a}$ & 10.7 & 9.1 & $3.5 \mathrm{~b}$ \\
\hline Control & $26.0 \mathrm{~b}$ & 9.9 & 10.1 & $2.5 \mathrm{a}$ \\
\hline$F \quad \mathrm{~T}$ & $6.73 * *$ & 0.33 n.s. & 0.89 n.s. & $5.26 * *$ \\
\hline$F \quad \mathrm{~B}$ & $6.92 * *$ & 0.88n.s. & $8.50 * *$ & $33.73^{* *}$ \\
\hline$F \mathrm{~T} \times \mathrm{B}$ & 2.59 n.s. & 0.58n.s. & 1.43 n.s. & $3.13 *$ \\
\hline
\end{tabular}

* $P \leq 0.05$;** $P \leq 0.01$. Within each column, means followed by different letters are significantly different $(P<0.05)$ according to the StudentNewman-Keuls test. ns, not significant; T, treatments; B, blocks. Cu: Poltiglia Disperss; CuS: Poltiglia Disperss+ Scudo; PhoS: PhosphitOne + Scudo

vines treated by $\mathrm{CuS}$ showed a grape yield of $4.7 \mathrm{~kg} / \mathrm{vine}$ (Table 4).

Must analyses showed that the control had a higher TSS than the other treatments $\left(26.0^{\circ}\right.$ Brix) (Table 5). This was probably related to the attack of downy mildew which reduced the number of berries and therefore increased the concentration of sugars. Titratable acidity (TA) and tartaric acid did not differ significantly among the treatments. Malic acid differed in a significant way among treatments, ranging from $2.1 \mathrm{~g} / \mathrm{L}(\mathrm{Cu}$ treatment) to $3.5 \mathrm{~g} / \mathrm{L}$ (PhoS treatment).

Anthocyanin and phenolics data were expressed as mg/berry (Table 6) and g/L (Table 7). Grapes from vines treated by Phosphit-One + Scudo (PhoS) showed the highest anthocyanin content (3.20 mg/berry) and phenolics content $(5.88 \mathrm{mg} /$ berry $)$ over the other treatments and the control (Table 6). Therefore, grapes from PhoS treatment, despite having a high berry weight, resulted in high concentration of polyphenols as well. As concerning the same parameters expressed as $\mathrm{g} / \mathrm{L}$, no significant differences were observed (Table 7).

The concentrations of copper in the must ranged from $1.2 \mathrm{ppm}$ (grapes from CuS treatment) to $5.2 \mathrm{ppm}$ (grapes from PhoS treatment), respecting the legal threshold of $50 \mathrm{ppm}$ (Table 8$)$. The copper residue $(1.8 \mathrm{ppm})$ of the untreated grapes is most likely due to a slight drift of product during the treatment. The phosphoric acid residue in the must of vines treated by Phosphit-One + Scudo (PhoS) was $22.7 \mathrm{ppm}$, below the legal limit (100 ppm). 
Table 6. Anthocyanins and phenolics of Barbera grapes depending on the treatments, at harvest.

\begin{tabular}{|l|c|c|}
\hline & $\begin{array}{c}\text { Anthocyanins } \\
\text { (mg/berry) }\end{array}$ & $\begin{array}{c}\text { Phenolics } \\
\text { (mg/berry) }\end{array}$ \\
\hline $\mathrm{Cu}$ & $2.19 \mathrm{a}$ & $4.40 \mathrm{a}$ \\
\hline $\mathrm{CuS}$ & $2.60 \mathrm{ab}$ & $5.31 \mathrm{ab}$ \\
\hline $\mathrm{PhoS}$ & $3.20 \mathrm{~b}$ & $5.88 \mathrm{~b}$ \\
\hline $\mathrm{Control}$ & $2.69 \mathrm{ab}$ & $4.91 \mathrm{ab}$ \\
\hline$F \quad \mathrm{~T}$ & $4.85 * *$ & $3.34 *$ \\
\hline$F \quad \mathrm{~B}$ & $13.66 * *$ & $7.86 * *$ \\
\hline$F \mathrm{~T} \times \mathrm{B}$ & 1.46 n.s. & 0.64 n.s. \\
\hline
\end{tabular}

$* P \leq 0.05 ; * * P \leq 0.01$. Within each column, means followed by different letters are significantly different $(P<0.05)$ according to the Student-Newman-Keuls test. ns, not significant; T, treatments; $\mathrm{B}$, blocks.

$\mathrm{Cu}$ : Poltiglia Disperss; CuS: Poltiglia Disperss + Scudo; PhoS: Phosphit-One + Scudo.

Table 7. Anthocyanins and phenolics of Barbera grapes depending on the treatments, at harvest.

\begin{tabular}{|l|c|c|}
\hline & $\begin{array}{c}\text { Anthocyanins } \\
(\mathbf{g} / \mathbf{L})\end{array}$ & $\begin{array}{c}\text { Phenolics } \\
(\mathrm{g} / \mathrm{L})\end{array}$ \\
\hline $\mathrm{Cu}$ & 0.95 & 1.93 \\
\hline $\mathrm{CuS}$ & 0.94 & 1.91 \\
\hline $\mathrm{PhoS}$ & 1.04 & 1.93 \\
\hline Control & 0.95 & 1.77 \\
\hline$F \quad \mathrm{~T}$ & 0.63 n.s & 0.45 n.s. \\
\hline$F \quad \mathrm{~B}$ & 0.10 n.s. & 0.88 n.s. \\
\hline$F$ T x B & 0.97 n.s. & 0.29 n.s. \\
\hline
\end{tabular}

* $P \leq 0.05$; ** $P \leq 0.01$. Within each column, means followed by different letters are significantly different $(P<0.05)$ according to the Student-Newman-Keuls test. ns, not significant; $\mathrm{T}$, treatments; $\mathrm{B}$, blocks. $\mathrm{Cu}$ : Poltiglia Disperss; CuS: Poltiglia Disperss + Scudo; PhoS: Phosphit-One + Scudo.

Table 8. Levels of copper and phosphites residues in musts of Barbera grapes, depending on the treatments, at harvest.

\begin{tabular}{|l|c|c|}
\hline & $\begin{array}{c}\text { Copper } \\
(\text { ppm })\end{array}$ & $\begin{array}{c}\text { Phosphites } \\
\text { (ppm) }\end{array}$ \\
\hline $\mathrm{Cu}$ & 1.6 & $=$ \\
\hline $\mathrm{CuS}$ & 1.2 & $=$ \\
\hline $\mathrm{PhoS}$ & 5.2 & 22.7 \\
\hline Control & 1.8 & $=$ \\
\hline
\end{tabular}

In the following graph (Fig. 1) are shown copper residues in comparison with the incidence of downy mildew attacks measured in August. The PhoS treatment showed a good level of protection and reduction of the doses of copper per hectare equal to $40 \%$. In fact, in 2015 were distributed $1.8 \mathrm{Kg} / \mathrm{ha}$ of $\mathrm{Cu}$ in PhoS treatment and $4.5 \mathrm{Kg} / \mathrm{ha}$ of $\mathrm{Cu}$ in $\mathrm{Cu}$ treatment. Also the treatment $\mathrm{CuS}$ performed well, allowing the best protection under a distribution of copper of $3.4 \mathrm{Kg} / \mathrm{ha}$.

\section{Conclusions}

The current trial was carried out during a year characterized by meteorological conditions quite favourable to downy mildew attack, and the month of July exceptionally hot. This situation had hindered the summer attacks of downy mildew; however the damage was consistent in

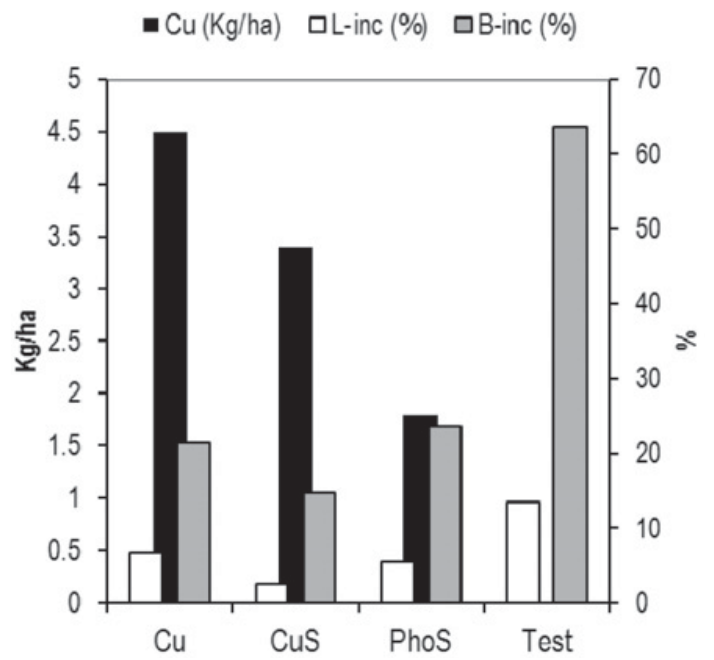

Figure 1. Level of downy mildew damages in August compared to the amount of copper distributed in the vineyard in 2015. L-Inc: leaf incidence; B-Inc: bunch incidence. $\mathrm{Cu}$ : Poltiglia Disperss; CuS: Poltiglia Disperss + Scudo; PhoS: Phosphit-One + Scudo; Test: control.

terms of yield/plant at harvest, resulting in a reduction of $30 \%$ in the control vines as compared to the treated ones.

The combination of traditional copper with organic phosphonate and Scudo has guaranteed the same protection to the canopy as the use of traditional copper, with a consistent reduction of the total amount of copper/ha ( $-40 \%$ for PhoS and $-22 \%$ for $\mathrm{CuS}$ ). Moreover, the harvested grapes showed contents of phosphonate and copper lower than the limits established by law.

\section{References}

[1] G. Fogliani, L'Informatore Agrario XXXIV, 1559 (1978)

[2] E. Baldacci, Vignevini VIII, 5 (1982)

[3] J. Branas, Storia e funzioni del rame nella viticoltura di qualità. Atti Convegno Internazionale: Il Rame e la Vite, 33 (1984)

[4] D. Boubals, G. Mur, O.F. Rivaldo, Progres Agricole et Viticole 96, 448 (1979)

[5] M.L. Gullino, G. Mancini, I. Scapin, Atti Giornate Fitopatologiche, 284 (1982)

[6] D. Kwon, H.K. Chung, W.S. Shinet, et al., Mol. Cell. Toxicol. 14, 105 (2018)

[7] M. Clerjeau, C. Moreau, B. Piganeau, G. Malato, Mededelingen van de Faculteit Landbouwwetenschappen Rijksuniversiteit Gent 49, 179 (1984)

[8] C. Gessler, I. Pertot., M. Perazzolli, Phytopathol. Mediterr. 50, 3 (2011)

[9] M.L. Gullino, E. Mescalchin, M. Mezzalama, Plant Pathology 46, 729 (1997)

[10] E. Kandeler, C. Kampichler, O. Horak, Biol. Fertil. Soils 23, 299 (1996)

[11] A. Morando, S. Lembo, P. Valaguassa, P. Morando, D. Beviore, L'Informatore Agrario 18, 71 (1999)

[12] S. Cravero, P. Bosca, D. Ferrari, I. Scapini, Valutazione dell' attività fungicidi di formulati tradizionali e nuovi per la lotta alla Peronospora della vite. Atti: Giornate Fitopatologiche 2, 155 (2000)

[13] A. Vercesi, R. Pontiroli, R. Rizzotti, Vignevini 5, 55 (2001) 
[14] A. Vercesi, M. Fregoni, S. Pezzutto, S. Civardi, M. Gatti, F. Ferrari, Ricerche sull'impiego di fosfito di potassio, estratti di alghe e rame nella difesa anticrittogamica e nella nutrizione della vite ed effetti sulla sintesi di fitoalessine fogliari. Atti: Convegno internazionale sull'impiego del rame in viticoltura", Torrazza Coste (PV) Azienda Sperimentale Riccagioia (ERSAF-Regione Lombardia), 1 dicembre (2006)

[15] A. Vercesi, M. Fregoni, M. Gatti, L. Gualdana, Ricerche circa gli effetti nutrizionali e sanitari su vite di formulati per irrorazione fogliare a base di miscele con microrganismi. Acta Italus Hortus n. 3, Atti del III Convegno Nazionale di Viticoltura (CONAVI) della Società Orticola Italiana - SOI, S. Michele all'Adige 5-9 luglio 2, 621-626 (2010)

[16] B. Speiser, A. Berner, A. Haseli, L. Tamm, Biol. Agric. Horticulture 17, 305 (1999)

[17] S. Cravero, E. Bassignana, P. Crovella, D. Ferrari, Atti Giornate Fitopatologiche 2, 289 (2002)

[18] A. Vercesi, P. Cosenza, M. Fregoni, Vignevini 4, 131 (2004)
[19] A. Vercesi, M. Fregoni, M. Gatti, L. Gualdana, M.I. Van Zeller, Ricerche circa gli effetti nutrizionali e sanitari su vite di irrorazioni fogliari a base di fosfati e fosfiti di potassio e magnesio. Acta Italus Hortus n. 3, Atti del III Convegno Nazionale di Viticoltura (CONAVI) della Società Orticola Italiana - SOI (S. Michele all'Adige 5-9 luglio 2, 517 (2010)

[20] L. Bavaresco, F. Mattivi, M. De Rosso, R. Flamini, Mini-Rev. Med. Chem. 12, 1366 (2012)

[21] V. Piglionica, P. Tarantini, G. Ferrara, Informatore Fitopatologico 27, 17 (1977)

[22] P.G. Iland, Proceedings 2nd International Cool Climate Viticulture and Oenology Symposium (Auckland, New Zealand, 1988), p. 137

[23] M. Anastassiades, D.I. Kolberg, A. Benkenstein, E. Eichhorn, S. Zechmann, D. Mack, C. Wildgrube, I. Sigalov, D. Dörk, A. Barth, Quick Method for the Analysis of numerous Highly Polar Pesticides in Foods of Plant Origin via LC-MS/MS involving Simultaneous Extraction with Methanol (QuPPeMethod) (2017) 